Title Page

\title{
English Philosophers and Scottish Academic Philosophy (1660-1700)
}

\section{Giovanni Gellera}

ORCID IDENTIFIER 0000-0002-8403-3170

Section de philosophie, Université de Lausanne

giovanni.gellera@unil.ch

The Version of Scholarly Record of this article is published in:

Journal of Scottish Philosophy 15/2 (2017): 213-231.

Published by Edinburgh University Press

https://www.euppublishing.com/doi/abs/10.3366/jsp.2017.0165

\begin{abstract}
This paper investigates the little-known reception of Thomas Hobbes, Henry More, Francis Bacon, Robert Boyle, Isaac Newton, and John Locke in the Scottish universities in the period 1660-1700.

The fortune of the English philosophers in the Scottish universities rested on whether their philosophies were consonant with the Scots' own philosophical agenda. Within the established Cartesian curriculum, the Scottish regents eagerly taught what they thought best in English philosophy (natural philosophy and experimentalism) and criticised what they thought wrong (materialism, contractualism, anti-innatism).

The paper also suggests new sources and perspectives for the broader discussion of the 'origins' of the Scottish Enlightenment.
\end{abstract}




\section{ENGLISH PHILOSOPHERS AND SCOTTISH ACADEMIC PHILOSOPHY (1660-1700)1}

The Anglo-Scottish relations during the "long seventeenth century" are intensely studied by intellectual historians: the political, social, economical, and military events of the period laid the foundations for later British history.2 The same is true for the history of British philosophy, but relatively little research has been done on the relations between English and Scottish philosophy in the seventeenth century. The reason is well known: until very recently, the consensus was that nothing of specific philosophical interest happened in Scotland in the seventeenth century, with the exception perhaps of the diaspora of intellectuals and students to the United Provinces and England. Some notoriously went as far as saying that "Scotland spent most of the century under a calvinist gloom, which allowed little if anything in the way of new ideas", and that "the universities were the unreformed seminaries of a fanatical clergy".3 Research has focused almost exclusively on the relations between seventeenthcentury English philosophy and eighteenth-century Scottish philosophy.

There is much to say for a better investigation of the relations between seventeenthcentury Scottish and English philosophy. The seventeenth-century Scottish philosophers were next-door neighbours of the great English philosophers of the time, as well as the direct predecessors of that unique philosophical blossoming that is the Scottish Enlightenment. It is reasonable to expect that these relations were more than a matter of geographical and temporal proximity. Recent research has confirmed that seventeenth-century Scottish philosophy has much to offer to historians of philosophy and intellectual historians alike. 4 Mainly the work of university teachers - with a handful of notable non-academic philosophers - seventeenth-century Scottish philosophy was rooted in Reformed scholasticism and lively enough to appropriate the philosophical novelties of France, the United Provinces, and England.

\footnotetext{
1 I thank the following audiences for their helpful comments [omitted for blind review]

2 For example, see the recent S. Adams and J. Goodare (eds), Scotland in the Age of Two Revolutions (Woodbridge - Rochester [NY]: Boydell \& Brewer, 2014.

3 This is the equally famous and wrong opinion of H. R. Trevor-Roper cited in C. M. Shepherd, "Newtonianism in Scottish Universities in the Seventeenth Century", in R. H. Campbell and A. Skinner, The Origins and Nature of the Scottish Enlightenment (Edinburgh: 1982), 65-85, 65.

4 The best accounts to date are A. Broadie, A History of Scottish Philosophy (Edinburgh: 2009) and S. Hutton, British Philosophy in the Seventeenth Century (Oxford: 2015).
} 
This investigation is not inconsequential for the vexed question of the "origins" of the Scottish Enlightenment. The terms of the debate are well known to the reader, so an introductory remark will suffice. The "continuist" view sees the origins of the Scottish Enlightenment in some pre-existing aspects of Scottish philosophy. The "non-continuist" view holds that the Scottish Enlightenment owes much (if not all) to philosophical developments elsewhere: England and the United Provinces are the best candidates for such an influence. No one, I believe, holds either position without a measure of nuances and qualifications. It is reasonable to believe that both aspects concurred to the Scottish Enlightenment. On the one side, Scottish philosophy was crucially influenced by English and Dutch philosophy, and by the intellectual network of the Republic of Letters. On the other side, even the best of influences falls dead without a proper receptive milieu. The Scottish Enlightenment could happen also because of the high-quality pre-existing philosophical tradition of seventeenth-century Scottish philosophy.

This paper surveys the reception of the major English philosophers in the philosophy teaching of the Scottish universities in the second half of the seventeenth century. The aim is to provide textual evidence and contextualisation as an invitation for further research. I will treat, in rough chronological order, Thomas Hobbes, Henry More, Robert Boyle, Francis Bacon, Isaac Newton, and John Locke. Other philosophers greatly mattered, but these are arguably the most representative English philosophers of the century - and the most represented in the Scottish universities. We will see how for some of them fame in England was matched by fame in Scotland, and how for others, in particular John Locke, this was not the case. I will argue that the fortune of the English philosophers rested on whether their respective philosophies were consonant with the Scottish universities' own philosophical agenda. The Scottish regents taught what they thought best in English philosophy, criticised what they thought wrong, but ultimately discussed everything, more or less faithfully. The regents' attitude seems one of active reception and relative open-mindedness - with the exception of those doctrines tainted with atheism and materialism.5

The reception of the English philosophers is thus a filter and a vantage point to investigate the regents' philosophy teaching and intellectual agenda. Natural philosophical interests tend to dominate the curriculum - as well as this paper - and dictate the regents' reading list of English philosophers. The universities are uniquely representative of (seventeenth-century) Scottish philosophy. Contrary to elsewhere in Europe, such as England and France, a great 
deal of the philosophical production came out of university teaching although notable nonacademic philosophers were active in the period.6 A final preliminary remark concerns the scope and temporal limits of my sources. I have privileged the graduation theses, usually titled Theses philosophica, because they are official university publications, bear the name of the regent who authored them, and present the most salient parts of the philosophy curriculum. Other sources are worth investigating for a full depiction of philosophy teaching, such as the library holdings and the occasionally undecipherable students' notes. Regarding the temporal limits: after 1660 are the attempts to reform the scholastic curriculum which gradually produced a "Cartesian" curriculum until the 1690s. The choice of the year 1700 suffers from a degree of arbitrariness but I take it to represent a turning point in the history of Scottish philosophy teaching, right before natural law, Newtonianism, the gradual end of the regenting system and of Latin as the philosophical language, and the first signs of the Enlightenment.

\section{The Background: Reformed Scholasticism and Cartesianism}

The citations of the English philosophers are second only to those of René Descartes and Aristotle. Aristotle is at once a polemical target and an authority: he is criticised as the old way of doing philosophy but praised in logic and moral philosophy. It is Descartes who had the strongest impact on the curriculum after 1670.7 Between around 1670 and 1700 the regents taught a philosophy curriculum inspired to Descartes in an original way. Two elements are important: 1) the regents produced a synthesis of Reformed scholasticism and Cartesianism. On both a principled and doctrinal level, the transition from scholasticism to Cartesianism does not cause the frictions, debates, and condemnations of Cartesianism seen elsewhere. Cartesianism was appealing to the regents because of its pedagogical value (a system which could compare to scholasticism), 8 and because of some doctrines: the

\footnotetext{
6 James Dalrymple, First Viscount Stair, author of the Physiologia Nova Experimentalis (Leiden: 1686). James Dundas, First lord Arniston, can now be acknowledged as a philosopher in light of the recent discovery of the manuscript of the Idea Philosophice Moralis (1679). Alexander Broadie and I are under contract with Edinburgh University Press for the critical edition and translation of the Idea. Pertinent to this paper is A. Broadie, "James Dundas on the Hobbesian State of Nature”, Journal of Scottish Philosophy 11 (2013), 1-13. Finally, Dundas' neighbour, George Mackenzie, author of the Religio Stoici (1663).

${ }_{7}$ C. M. Shepherd, Philosophy and Science in the Arts Curriculum of the Scottish Universities in the 17th century. $\mathrm{PhD}$ diss. (University of Edinburgh: 1975): passim. For example p. 337 for the comparison of Scotland and the United Provinces; Hutton 2015, chapter 2; G. Gellera, "The reception of Descartes in the seventeenth-century Scottish universities: metaphysics and natural philosophy (1650-1680)", Journal of Scottish Philosophy 13 (2015), 179-201; A. Raffe, "Intellectual change before the Enlightenment: Scotland, the Netherlands and the reception of Cartesian thought, 1650-1700”, Scottish Historical Review, 94 (2015), 24-47.

8 John Henry, The Reception of Cartesianism, in Peter R. Anstey (ed.), The Oxford Handbook of British Philosophy in the Seventeenth Century (Oxford, 2013), 117 and 136.
} 
Reformed strand of scholasticism of the Scottish universities anticipated some of Descartes' own views because of a common inclination towards Scotism.9 2) The reception of Descartes was not a mere repetition. Some views are reinterpreted by the regents in an original way, which suggests that they did not give up on some principles of scholastic philosophy they deemed fundamental.10

The resulting picture is a synthesis of Reformed scholasticism and Cartesianism. Distinctive features are: a fundamental empiricism in epistemology (trust in the senses, direct realism), a Christian substance dualism (metaphysics studies the spirits, natural philosophy studies the natural bodies), reductionism in the theory of substance (the accidents are modes of the substances), a foundationalist structure of knowledge. With this background in mind we can investigate the reception of the English philosophers.

\section{Thomas Hobbes}

Thomas Hobbes is the archetypical polemical target of the Scottish regents. He is the single most cited English philosophers, overwhelmingly in a negative way. He is, in turns, “ineptus",11 "fumivendulus". “monophagus", 12 "delirans”, 13 “crassissimus", 14 cursed,15 on a par with Vaninus and Spinoza, 16 "horrendus".17 These epithets are not really surprising, considering Hobbes' reputation as an atheist throughout the seventeenth century. In the mind of the regents, Hobbes' atheism came from his materialism: they reacted from a Christian perspective to the views of the materiality of the soul, and to the negation of the existence of spirits and substantial forms in metaphysics and natural philosophy. The regents draw from a number of Hobbes' texts, mainly the Leviathan for his political and moral thought and the De corpore for his natural philosophy. Many Hobbes citations are in Hamilton's theses (1668) and Alexander's theses (1669). The latter are particularly interesting because Hobbes is criticised for his nominalism in logic, for the views that truth is a property of propositions and

\footnotetext{
9 R. Ariew, Descartes and the Last Scholastics (Ithaca - London: 1999), 55: "Descartes leans toward Scotism for every one of the Scotist theses, as long as they are relevant to his philosophy." 10 [omitted for blind review] 11 R. Hamilton, Schediasmata Libero-Philosophica (Edinburgh: 1668, St Salvator's College), I. 12 A. Alexander, Philosophemata Libera (Aberdeen: 1669, Marischal College), Ethical Theses III, Physical theses II.

13 H. Scougal, Positiones hasce Philosophicas (Aberdeen: 1673, King's College), VII-VIII: against contractualism and relativism.

${ }_{14}$ G. Middleton, Theses philosophica (Aberdeen: 1675, King's College), XXVI, for Hobbes' negation of spirits. 15 J. Buchan, Theses Philosophica (Aberdeen: 1681, King's College), XXX: against the view that ratiocinatio is a conventional association of words.

16 T. Burnet, Theses Philosophica (Aberdeen: 1686, Marischal College), II, because of his atheism. ${ }_{17}$ G. Peacock, Theses Philosophicae (Aberdeen: 1697, Marischal College), V. On the negation of the immortality of the soul.
} 
not of substances, and that thinking is grounded on speech.18 Again, not surprisingly, Hobbes is criticised for being a contractualist in moral and political philosophy, which leads to relativism and the negation of God's rational nature. 19

Hobbes political philosophy faces heavy criticism. The Scottish universities were, prima facie, potentially sympathetic with Hobbes' theory of the state. In opposition to the overall narrative of a limited monarchy tradition in Scotland,20 the regents always defend the absolute power of the king deriving from the sole divine authority.21 They seem to be oblivious here of John Duns Scotus, whom they otherwise often cite favourably.22 Another proponent of limited representative monarchy, the Humanist George Buchanan, is strongly attacked in the theses by James Martin (1681) in the only reference to him in the seventeenthcentury theses.23 In general, the regents very rarely engage with political themes. Before the introduction of natural law by Gershom Carmichael in the late 1690s, political philosophy has a very minor role in the theses, and is more conservative and scholastic than the other disciplines. 24

The Exclusion Crisis (1679-1681) might have motivated more open positions in the early 1680s. The theses by regents James Martin and John Buchan, both from 1681 and from the two Aberdeen colleges Marischal and King's respectively, have strong political tones. Hobbes is (even!) accused of being a revolutionary, for his view that a subject can revolt against the sovereign in order to preserve his life.25 In Martin's theses, paragraph XIII is a defence of the God-sanctioned royal succession, which cannot be changed by men. In Buchan's theses, the conclusive paragraphs LXXVIII to LXXXVI attack Hobbes on the origin of good and evil, on the view that kings are bound by natural law, and on the

\footnotetext{
18 Alexander 1669, Logical Theses. 19 Buchan 1681, LXXXIX.

20 K. Bowie, "“A legal limited monarchy': Scottish constitutionalism in the Union of Crowns, 1603-1707”, Journal of Scottish Historical Studies 35 (2015), 131-154.

21 For example: J. Martin, Positiones Philosophicae (Edinburgh: 1681, Marischal College), Ethico-Political Theses X, where King Charles is called a "martyr"; and Burnet 1686, IV where James VIII is called "absolutissimus Monarcha Scotiæ."

22 Broadie 2009, 25-31 for the origins of Scottish contractualism in Scotus.

23 Martin 1681: the whole Ethico-Political section is an attack of Buchanan's contractualism and limited monarchy.

24 Ronald G. Cant has argued that after the Stewart restoration in 1660 the traditional religious and political control over the universities focused more on political conservatism than religious orthodoxy. This might have contributed to the expansion of "whole areas of investigation in which considerations of civil and ecclesiastical polity simply did not arise", such as mathematics and natural philosophy. "Origins of the Enlightenment in Scotland; the Universities", in R. H. Campbell and A. Skinner, The Origins and Nature of the Scottish Enlightenment (Edinburgh: 1982), 42-63, 43.

25 Buchan 1681, LXXIX. See Broadie 2013, 3 on a similar criticism moved by James Dundas to Hobbes: "the chief point in natural law is not what Hobbes thinks it is, that each person has a right to use all ways and means to preserve himself."
} 
aforementioned dangerous principle that a citizen can revolt to defend their life, forbidden by the Bible. Finally, paragraph LXXXVI explicitly takes the "Tory" side in the Exclusion Crisis: the Stuart succession is above positive law, royal authority does not reside in the people who cannot limit or transfer it. Indeed, "potentissimus erit populus: sed in suam ruinam." Arguably, the tragedy of the civil war still loomed in the minds of the regents, and translated into the defence of absolute monarchy for fear of political instability. The conservative Aberdeen publicly sided with the king in the Exclusion Crisis in the persons of Martin and Buchan. Though it might be fitting for a regent teaching at "King's College", such a rare (in the theses) political statement had clear Catholic and pro-absolute monarchy connotations.

\section{Henry More}

Henry More and the Cambridge Platonists have recently seen their relations with the Scottish Enlightenment re-evaluated.26 The Scottish regents show a constant interest in Henry More from the 1670s on. More (and Boyle) is the "Christian and modern" philosopher par excellence. Such credentials are based on his defence of the spirits and immaterial principles within the new metaphysics inaugurated by Descartes: namely, substance dualism. Henry More "moderates" the potential excesses of Cartesianism: a mechanistic understanding of the universe potentially dismissive of God's role, and a reductionist metaphysics with all substances (not only corporeal ones) being nothing more than modifications of matter - so to speak, a Hobbesian interpretation of Descartes.

More is acknowledged as an authority in moral philosophy, especially in the theory of the passions. In pre-natural law philosophy teaching, the theory of the passions was influenced by Descartes' moral philosophy. There are passages from the graduation theses which are very close citations of More's Enchyridion Ethicum.27 In addition to this text, the regents studied the correspondence between Descartes and More, first published in 1662.28 Although More's sentimentalist views are only rarely mentioned,29 More's later importance in the Scottish Enlightenment can be seen through his continuous presence in university teaching.

26 M. B. Gill, "From Cambridge Platonism to Scottish Sentimentalism", Journal of Scottish Philosophy 8 (2010), 13-31; S. Hutton, "From Cudworth to Hume: Cambridge Platonism and the Scottish Enlightenment", Canadian Journal of Philosophy 42 (2012), 8-26.

27 For example: Middleton 1675, XLV on the definition of virtue.

28 Hutton 2015, 65.

29 Hamilton 1668, Ethical Theses I on happiness, boniform faculty, and self-love. 
A similar, yet much minor, role in the theses plays Ralph Cudworth. In 1684 Cudworth's defence of spirits in physics is invoked by regent Robert Forbes in his attack against Descartes supposed "materialism".30

\section{The "Experimentalists": Robert Boyle, Francis Bacon, and Isaac Newton}

Among the English philosophers, the "experimentalists" are, collectively, the most cited ones. They alone represent around half of the total citations in the graduation theses, with the exception of Aristotle and Descartes. There is evidence that the experimentalists are systemic in the philosophy teaching, far more than Henry More is.

Treating philosophers so diverse as Bacon, Boyle, and Newton under the same heading requires an explanation. The expression "experimentalists" helps pick out the fact that, according to the regents, these thinkers contributed to the same narrative: that the new physics, and experimentalism above all, is the best theory of the physical world because it improves and expands Descartes' notion of res extensa, and provides a better natural theology. The (scholastic) distinction here is between general physics and special physics. The former deals with the general principles of bodies: here, Descartes' is unsurpassed, in that he provides a Christian metaphysics of the physical world, and a clear distinction between the immaterial and material worlds. Special physics deals with the specific properties of the bodies: here Descartes (for example: on the vortex theory, inertia, light, and colour) is improved or surpassed by the English experimentalists. Additionally, this enthusiasm for the experimentalists signals a fundamental optimism about the present state and future of philosophy. The regents recurrently celebrate "hujus sæculi genius" for setting philosophy and the knowledge of the external world on a successful course, and the "Felix philosophiæ incrementum".31 Almost absent are the criticisms of the new philosophy, especially Cartesianism, in the name of allegiance to scholasticism, Aristotle, or the true religion, which were very common elsewhere in Europe. The opposition to Descartes, though present and lively especially in the Presbyterian circles, was much less visible in the Episcopalian-controlled universities.32 The fortune of Descartes and of the English experimentalists is quite interesting also because it suggests a perhaps unexpected openmindedness of the Scottish regents.

\footnotetext{
30 R. Forbes, Theses Philosophica (Aberdeen: 1684, King's College), IX. 31 Buchan 1681, LXXVI.

32 Raffe, "Intellectual change before the Enlightenment", 26; and G. Gellera, "The Philosophy of Robert Forbes: a Scottish Scholastic Response to Cartesianism” Journal of Scottish Philosophy 11.2 (2013): 191-211.
} 
The new physics as it is understood by the Scottish regents is a mixture of old and new. It is not a deductive, a priori discipline, as in scholasticism, yet it still is about the knowledge of the essence of things. It is not a full experimentalist discipline either, though the praises of experientia are recurrent. It is not dependent from metaphysics in the way scholastic natural philosophy was; rather, it is dependent from metaphysics because coherence with the Cartesian metaphysics of substance dualism is a requisite. It is, in good English experimental spirit, increasingly understood as a natural or physico-theology which replaces the traditional metaphysical proofs of the existence of God.33 Neither is it a mathematical theory of the natural bodies: the regents lacked the adequate mathematical background. There is still a clear qualitative aspect in the understanding of the natural phenomena as dependent on the essence of matter, although this essence is solely explained in terms of modifications and movement according to the new science.

Bacon, Boyle, and Newton represent, respectively, different aspects of the new science. I treat them in order of their importance in the graduation theses.

\section{Robert Boyle}

Robert Boyle is second only to Descartes in the consideration of the regents. His praises are as numerous as are Hobbes' epithets. Boyle is, with Rohault, the "Castor and Pollux" of modern science and "naturæ peritissimus",34 "Anglorum ingenium" and a "præponderans authoritas",35 "gentis et sæculi ornamentum",36 "Regiæ Societatis ornamentum”, 37 "eximius".38 What is the specific merit of Boyle? A passage of John Buchan's theses (1681) answers the question:

The most knowledgeable and most ingenious Robert Boyle, in his treatise On Forms, and Qualities, presents a short but exact summary of mechanical philosophy. He states that, first, the matter of all bodies is the same, namely an extended and impenetrable substance. Secondly, that movement does not belong

\footnotetext{
33 Chairs of Mathematics were established at the Scottish universities in the second half of the century. Notable professors were James Gregory at St Andrews and Edinburgh and the anti-Cartesian George Sinclair at Glasgow, whose Chair included 'experimental philosophy'. Despite this, the academic connection between mathematics and natural philosophy was rarely there until the Newtonianism combined them towards the end of the century. On the emergence of physico-theology: Peter Harrison, "Physico-Theology and the Mixed Sciences: The Role of Theology in Early Modern Natural Philosophy," in Peter R. Anstey and John A. Schuster (eds), The Science of Nature in the Seventeenth Century. Patterns of Change in Early Modern Natural Philosophy (Dordrecht: 2005), 165-184.

34 Hamilton 1668, Logical Theses, V; Physical Theses, VII.

35 Alexander 1669, Physical Theses, I and III.

36 Scougal 1673, XIV.

37 A. Massie, Theses Philosophicae (Edinburgh: 1687, University of Edinburgh), XI.

${ }_{38}$ G. Skene, Decermina haec Philosophica (Aberdeen: 1696, King's College), IX.
} 
to the essence of matter, neither is it produced by the accidents of matter; rather, it is matter's first and particular mode. Thirdly, that the differences between bodies are explained by their accidents. Fourthly, that the various determinations of movement naturally divide matter into different parts [...].39

Buchan lists eight doctrines characteristic of mechanical philosophy which are most aptly expressed by Boyle. This consideration of Boyle as a systematiser of mechanical philosophy is perhaps surprising, considering Boyle's own "reluctance to systematize".40 I believe that Buchan is not so much interested in understanding Boyle's approach to science; rather in what Boyle's role in the philosophy curriculum of the universities could be. Hence, the $O n$ the Origins of Forms and Qualities represents the best introduction to mechanical philosophy available, of great pedagogical value to students. As for the reception of Henry More, another crucial aspect is Boyle's theology: the Christian interpretation of the new science and its capacity to replace metaphysics as a natural theology is a central concern in the regents' philosophy.41

\section{Francis Bacon}

Francis Bacon is a relatively late entry in the bibliography of the graduation theses. Before the 1680s there is only one reference to Bacon in Hamilton's theses (1668), albeit a very important one:

As Bacon says, our intellect invite for the help of the things in order to perfect its own thinking. 42

Bacon's method is directed towards the investigation of the external things, which are the high way to improve our knowledge and intellect. Hamilton is celebrating the empirical method, with the implicit criticism of the overly speculative approach to natural philosophy typical of the scholastics and of the Cartesian alike. By the end of the 1680s, more regents

\footnotetext{
39 Buchan 1681, XXXVI: "Brevem, sed exactam Philosophiæ mechanicæ summam, exhibet eruditissimus \& maxime ingeniosus Philosophus D. Rob. Boyl, in tractatu suo de Formis, \& Qualitatibus, observando, Primo, omnium corporum materiam esse eandem, substantiam sciz. extensam \& impenetrabilem. Secundo, motum neque esse essentiam materiæ, neque ab aliis accidentibus produci; sed esse illius primum et præcipuum modum. Tertio, diversitatem inter corpora ab eorum accidentibus ortum ducere. Quarto, motum varie determinatum, naturaliter dividere materiam in partes [...].” All translations are my own. Skene 1696, IX likewise claims that Boyle provides the best summa of mechanical philosophy.

40 Hutton 2015, 173.

41 For example, Alexander 1669, Physical theses, IV, celebrates Boyle's experimental philosophy which contemplates and concatenates the natural phenomena as a natural theology, and opposes it to Hobbes' materialistic Natura naturans; and Metaphysical theses, III: "Rob; Boyl: \& Henrici Mori, qui non sine successu, naturalem DEI cognitionem manifeste elucubrant."

42 Hamilton 1668, V: “Ut loquitur F. B. Verul. Intellectus noster accersit auxilia a rebus ad perficiendam sui cogitationem."
} 
identify Francis Bacon as the master of philosophical method, a title previously held by Descartes. Whereas Keith's theses of 1687 mention only Descartes in the discussion of the prajudicia infantice (a topos of Bacon's philosophy), Peacock in 1689 reverses the narrative: The most famous Descartes was much guided by the light of this founder of arts and sciences [Francis Bacon]. Descartes, who ushered in a new logic, under the name of metaphysics or meditations, imitated Bacon to the point of creating a new philosophy from its foundations. He wanted to depose all prejudices, and decided to build all the rest using a firm principle as a basis, once he found one. Anyway, he did not follow the same path as Bacon: whereas Bacon looked for the help of the external things in order to improve the intellect, Descartes claimed that there is enough help in our thinking that the mind can, by its own strength, get to know all things.43

According to Peacock, Descartes has imitated Bacon in the philosophical method, although he has diverted from Bacon's original point. Descartes' rationalism brought him to rely on the sole mind in the quest for truth, whereas Bacon directed the mind towards the external things - making the same point as regent Hamilton (1668). This latter remark encapsulates a fundamental and original revision of Descartes in Scottish Cartesianism: empiricism takes the place of rationalism as the foundation of knowledge. 44 Bacon perfectly embodies this approach, although it is plausible that, after all, Bacon's role in the theses does not go much further than a general nominal praise. Later, in the theses of 1693, Peacock mentions Bacon's method as "inductive". 45 In the same theses, Peacock presents the triad of the new philosophy:

We rejoice in the genius of the present century, which rejected the Epicurean, the Vain and overly celebrated principles of the Chemists, Salt, Sulphur, and Mercury, as well as the Substantial Forms and Prime Matter of the Peripatetics. Our century with the Noble Bacon, Descartes, and Boyle laid out the genuine foundations of Philosophy, and stated the true principles of the natural bodies,

\footnotetext{
43 G. Peacock, Theses Philosophicae (Aberdeen: 1689, Marischal College), I: "Ab hoc artium \& scientiarum instauratore, multum lucis foveratus est Claris. Cart. qui logicam quandam novam, sub Metaphysicæ vel meditationum nomine invexit, Verulamium eatenus imitatus, quod novam Philosophiam a fundamentis excitaturus, seponere voluerit omnia præjudicia, \& quodam principio firmo detecto, huic tanquam basi, reliquam superstuere molem decreverit: non eandem tamen viam quam Verulamius est ingressus cum enim ille auxilia a rebus ad perficiendum intellectum petierit, hic vero satis præsidii esse autumabat in ipsa cogitatione, ut mens possit vi sua, in omnium rerum cognitionem pervenire."

44 The earliest "empiricist" version of Cartesianism was given by the Utrecht physician Henricus Regius. There is no evidence that the regents' interpretation of Descartes originated in Regius. See also Gellera, "The Reception of Descartes", 190-191. 45 G. Peacock, Theses Philosophica (Aberdeen: 1693, Marischal College), IV.
} 
namely matter and movement, combined with magnitude or figure and the other dispositions of the bodies. 46

Perhaps to the reader's surprise, Isaac Newton is not there.

\section{Isaac Newton}

We are accustomed to the view that in the early eighteenth century "Newtonianism" replaced the philosophy previously taught in the Scottish universities, 47 and that most of the achievements of the Scottish Enlightenment can actually be regarded as different ways of applying the Newtonian method in philosophy, as David Hume famously said.48 Scotland had much to do with the early dissemination of Newtonianism, and Newton enjoyed a vast popularity in the eighteenth-century Scottish universities. The situation is rather different until the end of the seventeenth century.49 In this period, the Scottish mathematicians saw Newton's greatness before the natural philosophers did.50 Newton is known by the regents as the author of an important experiment on light and colour as early as 1674,51 and his name is only linked to this specific debate (where his view is always preferred over Descartes') and to his dismissal of the Cartesian vortices (his view is often preferred over Descartes').52 The situation does not change with the publication of the Principia mathematica in 1687. Newton is a "mathematicus": he is not credited with a novel philosophical method, or with any

46 Peacock 1693, VI: “Gratulamur fœlici hujus ævi genio, quod rejectis Epicureorum Atomis \& Inani ac decantatis Chymicorum principiis Sali, Sulphuro \& Mercurio, Peripateticorum etiam Materia prima \& Formis substantialibus cum Nob. Verul. Cart. Boylio \&c. genuina jecerit Philosophiæ fundamina, \& vera corporum naturalium statuminaverit principia, nempe materia, et motum, una cum magnitudine sive figura, aliisque corporum dispositionibus."

47 P. Wood, "Candide in Caledonia: the Culture of Science in the Scottish Universities", 1690-1805, in M. Feingold (ed.), Universities and Science in the Early Modern Period (Dordrecht: 2006), 182-199, 191; Hutton 2015, 45; Raffe 2015, 26.

48 D. Hume, A Treatise of Human Nature, edited by L. A. Selby-Bigge (Oxford: 1960), Introduction, xx: “'Tis no astonishing reflection to consider, that the application of experimental philosophy to moral subjects should come after that to natural at the distance of above a whole century." Although Hume's own Newtonianism might be limited to few methodological remarks.

49 For a survey of graduation theses and lecture notes: C. M. Shepherd, "Newtonianism in Scottish Universities in the Seventeenth Century", in R. H. Campbell and A. Skinner, The Origins and Nature of the Scottish Enlightenment (Edinburgh: 1982), 65-85.

50 In particular, the circles around the Gregory family, James and the two David.

51 In 1674 Newton was known only for the article "New Theory of Light and Colours" published in 1672 in the Philosophical Transactions. A likely source of the early reception of Newton in St Andrews is the presence there of James Gregory, appointed to the Chair of Mathematics in 1668. Niccolò Guicciardini, 'Gregory, James (1638-1675)', Oxford Dictionary of National Biography, Oxford University Press, 2004

[http://www.oxforddnb.com/view/article/11465, accessed 17 May 2016]

52 For example, William Sanders, Theses Philosophicae (Glasgow, 1674, St Leonard's College), XX; Alexander Cockburn, Theses philosophica (Edinburgh, 1675, St Leonard's College), XXXII; Middleton 1675, XV; Martin 1681, XI; Gilbert MacMurdo, Theses hasce Philosophicas (Edinburgh, 1682, University of Edinburgh), XVII; More 1691, XVIII; Peacock 1697, VIII. Newton dismisses the vortices: George Fraser, Positiones aliquot philosophicae (Aberdeen, 1691, King's College), IX; Alexander Fraser, Determinationes philosophicae (Aberdeen, 1693, Marischal College), XIX. 
importance in disciplines other than special physics and astronomy. What was arguably needed for a "philosophical Newton", or a "Newton for the Faculties of Arts", was something akin to George Turnbull's intuition to develop the potentialities of "Newtonian method" and apply it to the whole of philosophy. 53

A glimpse of "Newtonian method" is in the introductory paragraph of Kennedy's theses of 1694. Under the suggestive heading "Demens qui voluit rerum cognoscere causas" - at once gesturing at Newton's rejection of essentialist talks and echoing at a distance Calvin's distrust of the powers of the human faculties in the post-lapsarian state - Kennedy claims that:

Descartes gave us a hypothesis, that is, a Fable, not Philosophy. Newton showed us Philosophy, not a hypothesis. He is the one who laid down the first foundations of Philosophy, and the First one who carried up philosophy from the foundations to the heavens: those who ascribe to Newton only a hypothesis are plain wrong. 54

Kennedy praises here both the intension and extension of Newton's philosophy: he mastered method because he laid out the foundations, and he obtained comprehensiveness because his theory embraces the terrestrial as well as the celestial world. In a quasi-anticipation of the famous "hypotheses non fingo",55 Newton is, for the first and only time in the seventeenthcentury theses, alternative to Descartes with respect to the general theories of the natural world, and not only to particular theories in special physics. In Kennedy's mind, Newton comes with a distinctive philosophy and a method, though admittedly this high praise is not really followed by a presentation of Newton's views in the remainder of Kennedy's theses. It is suggestive to think that Kennedy's original view of Newton might have been influenced by the Newtonian circle around Alexander Pitcairne and David Gregory in Edinburgh.56 On

53 Wood 2006, 190; Broadie 2009, 111: “The title page of Principles of Moral Philosophy [...] contains a quotation that Turnbull first uses in his graduation oration of 1723, from Sir Isaac Newton's Opticks, bk. III: 'And if natural philosophy, in all its parts, by pursuing this method, shall at length be perfected, the bounds of moral philosophy will also be enlarged.",

54 R. Kennedy, Theses hasce Philosophicas (Edinburgh: 1694, University of Edinburgh), I: "Hypothesin, i.e. Fabulam, non Philosophiam dedit Cartesius: Philosophiam, non Hypothesin exhibuit Neutonus. Hic ille est qui prima Philosophiæ fundamenta jecit, ipsamque Primus a fundamentis in Coelum evexit: Falluntur ergo qui Neutono Hypothesin attribuunt."

55 The reference is not a direct one, for Newton used the expression for the first time in the second edition of the Principia in 1713. Anstey argues that among the English philosophers "the Cartesian system is used as an example of a hypothetical system”, P. R. Anstey, "Experimental versus Speculative Philosophy," in P. R. Anstey and J. A. Schuster (eds), The Science of Nature in the Seventeenth Century. Patterns of Change in Early Modern Natural Philosophy (Dordrecht: 2005), 215-242, 229. Kennedy's incipit might hint at the "antihypothesis" rhetoric of the English debates in the 1690s, to which Newton decisively contributed.

"Hypothetical" (that is, not physical) was also the ontological status of mathematical accounts advanced by the Jesuits in order to keep natural philosophy and mathematics separate.

56 A. Guerrini, "The Tory Newtonians: Gregory, Pitcairne, and Their Circle”, Journal of British Studies 25 (1986), 288-311. 
paragraph IV, Kennedy laments David Gregory's departure for Oxford: “D. Gregorio olim noster nunc Oxoniensis."

By the end of the seventeenth century, Isaac Newton, always praised but somehow distantly referred to as "Cantabrigensis", seems to be rising to the high rank he will occupy in the eighteenth century. Francis Bacon acquired in the 1680s the status of master of method, and rivalled Descartes. The main household name is Robert Boyle: he is the most celebrated among the experimentalists, he produced the most exact mechanical science, and he best represents the new natural theology based on experimental method. In the general framework of Scottish Cartesianism, it is still Boyle who produced the best theory of matter and movement. Arguably, this "Scottish Boylianism" of the regents of Arts would have been hardly recognised by Boyle himself.

\section{John Locke}

John Locke was immediately recognised by his own contemporaries as a great philosopher, 57 so his relative absence from the graduation theses in the late seventeenth and early eighteenth century begs an explanation. The Scottish regents were quick to grasp the importance of Locke's An Essay Concerning Human Understanding published in 1690, but they were unequivocal in dismissing it altogether as against their philosophy. Here and elsewhere, the agreement among the regents is quite remarkable, and really suggestive of the existence of a common curriculum across the Scottish universities, albeit not an officially sanctioned one. The de facto curriculum was rather based on the widespread adherence to Reformed scholastic and Cartesian themes. I believe that Locke's fate in the Scottish universities was sealed by the impossibility to build a university curriculum on Locke's philosophy, and by the incompatibility of some central Lockean views and the Scottish curriculum at the time. These factors combined explain the very minor role Locke plays in the theses. 58

Nonetheless, the only four references to Locke are very interesting. The first one is by Alexander More, in his 1691 theses:

Since the idea of God is innate, that Englishman John Locke can be accused of falsity, who recently wrote in his book on the human intellect that the human

\footnotetext{
57 Hutton 2015, 46. 58 P. Wood, The Aberdeen Enlightenment: the Arts curriculum in the Eighteenth Century (Aberdeen: 1993), part 1, argues for a more prominent role of Locke in the university teaching. So does Shepherd 1975, 339: "though the Cartesian method is recommended from the 1670 s, and it in turn is superseded by Locke's philosophy." I have found no convincing evidence for these claims.
} 
mind is a tabula rasa without any ideas, and that there are in it no innate principles speculative and practical.59

The second and third ones are in the 1697 theses by John Loudon. In paragraph X Locke is criticised for favouring atheism too much with his philosophy ("Ut ad Atheismum facilius aperiatur via”, paragraph X) because, as a Deist, he rejects the infinite idea of God - perhaps, the regent accepts the Cartesian notion of infinity and ascribes something like Gassendi's notion to Locke. In paragraph XII, his rejection of innate ideas is again targeted:

God exists, and his light, without any other arguments needed, seizes the mind and forces its assent. Hence, I cannot make sense of why John Locke fights against the Innate Ideas, by means of complicated sophistries, as if he were fighting with his own shadow.60

The final reference is in the 1696 theses by Skene, paragraph II: there Locke is accused of maintaining the soul in an "ergastulo corporeo", arguably in light of his scepticism about the immateriality of the soul and the view that matter can think. These regents believe that a version of strong innatism is the best account of the nature and presence in our mind of the idea of God. This position might well be an exaggeration of Descartes' view influenced by the Calvinist sense of divinity.

It is quite evident that the regents did not go much beyond Book I of the Essay, and that what they read there against the innate ideas was enough to dismiss the Anglus Locke. There might also be non-philosophical reasons which added more weight to the philosophical ones. As a member of the English Board of Trade, John Locke was heavily involved in the ultimately successful English manoeuvring against the Scottish colonial expedition at Darien. The linkage of Locke's name to the dire consequences of the expedition would have overshadowed the brightest philosophical achievements of the Anglus Lockius.

\section{Non-English philosophers: Gassendi}

59 A. More, Theses Philosophica (Aberdeen: 1691, Marischal College), III: “Cum itaque innata sit hæc Dei idea, falsitatis merito sinsimulandus est nuperus quidam Anglus Ioan. Lock. in lib. cui tit. humanus intellectus, in quo asserit mentem humanam esse tabulam rasam omnibus ideis vacuam, \& in ea nulla esse principia innata speculativa vel practica." The regent attributes the expression "tabula rasa" to Locke, who never used it in the Essay. The expression is common in the theses: as early as Alexander 1669, Logical Theses III, who celebrates Henry More for arguing that the mind is not a tabula rasa. 60 J. Loudon, Theses Philosophica (Edinburgh: 1697, St Leonard's College), XII: “Deus existit, ut luce sua, absque argumentis aliunde adductis, mentem in assensum rapiat. Unde nihil est reliquum cur, operosis adeo cavillationibus, quasi cum umbra sua luctaretur, [...] Innatas Ideas impugnet Jo. Lockius.” Later, G. Peacock Theses philosophicae (Aberdeen: 1711, Marischal College), V, reiterates the same point against Locke. 
The analysis of the citations of non-English philosophers sheds further light on the importance of the English philosophers in Scottish philosophy teaching. For reasons of space I can only make a very general remark. The most cited non-English philosopher is the French Pierre Gassendi,61 followed by the Dutch Adriaan Heereboord - second only to Descartes. They are cited, respectively, as many times as Boyle and Bacon. Gassendi is cited six times in Hamilton 1668 and Alexander 1669, four times in Buchan 1681, twice in Burnet 1686, and few more times in later theses. Gassendi is almost exclusively cited in natural philosophy, which confirms its importance in the curriculum. With respect to Boyle, though, there is neither an identifiable pattern nor overall impact of Gassendi on the theses and his citations seem sporadic. By the 1680s his importance declines rapidly right at the time of the increasing importance of the English experimentalists.62

\section{Conclusion}

The importance of the English philosophers in the Scottish universities is explained by the close relations between England and Scotland and by the high quality of the philosophical achievements south of the Tweed. While keeping the English philosophers at arm's length (they are invariably "Anglus", "Cantabrigensis"), the Scottish regents were keen to learn from them. The Scottish universities were part of an intellectual and academic community whose identity was increasingly identifiable as British.

Arguably though, the Scottish regents did not beat the national drum of the English (let alone the British) philosophers vis-à-vis the system of the French Descartes. The national element is not there in the same way as it was in the calculus controversy between supporters of Newton and Leibniz, or in eighteenth-century French Cartesian resistance to Newtonianism. The regents did not contribute new experiments: as in Glasgow, "experimental philosophy" was rather within the remit of mathematics chairs. The regents did not usually have a specific background in mathematics either: the relatively accessible Boyle was a philosophus, while the highly technical Newton was a mathematicus. Curriculum concerns prevailed. The regents thought as natural philosophers within a coherent structure of philosophical disciplines, rather than as experimental philosophers or mathematicians. They believed that English experimentalism and empiricism were compatible with Descartes' metaphysics, that they provided a better physics than Descartes', and that Boyle's natural

61 Hutton 2015, 61-63 on Gassendi and British philosophy.

${ }_{62}$ Heereboord's case is less interesting. Citations are limited to very few sets of theses mainly in the 1660s and seem even more sporadic than Gassendi's. The teaching of Pufendorf and Grotius, especially in Gershom Carmichael's theses, appears only at the close of the century. 
theology was preferable to the a priori proofs of the Meditations. The regents remained Cartesian in the fundamentals of their philosophy, a Cartesianism born out of Reformed scholasticism.

This brings us to a final remark on the relations between seventeenth and eighteenth centuries in British philosophy. Sarah Hutton has recently reviewed the two main narratives as follows:

On one view Locke is the seventeenth-century philosopher for the Enlightenment, the philosophical spokesman of empiricism and representative of the natural law tradition, and bringing in his train the natural philosophers Boyle and Newton as well as Bacon and Cumberland [...] On Another view it is Shaftesbury who forms the bridge between seventeenth-century British philosophy and the Enlightenment-Shaftesbury as anticlerical heir of Hebert of Cherbury, and father of eighteenth-century sentimentalism.63

Elaborating on the remark that "neither view captures the complexities and scope of the eighteenth-century philosophy",64 I would like to suggest a third view. In the early eighteenth-century Scotland, the respective tendencies towards Locke and Shaftesbury - just like the earlier tendencies towards More and the Experimentalists, and against Hobbes and Locke - were received in, and mediated by, the seventeenth-century synthesis of Reformed scholasticism and Cartesianism. This synthesis has an important place in the investigations of the relations between English and Scottish philosophies in the seventeenth and eighteenth centuries. In this synthesis one can find the worldview and philosophical interests of the generations of Scottish philosophers before the Enlightenment.

\section{Bibliography}

S. Adams and J. Goodare (eds), Scotland in the Age of Two Revolutions (Woodbridge Rochester [NY]: Boydell \& Brewer, 2014

A. Alexander, Philosophemata Libera (Aberdeen: 1669, Marischal College)

P. R. Anstey, "Experimental versus Speculative Philosophy,” in P. R. Anstey and J. A.

Schuster (eds), The Science of Nature in the Seventeenth Century. Patterns of Change in

Early Modern Natural Philosophy (Dordrecht: 2005), 215-242

R. Ariew, Descartes and the Last Scholastics (Ithaca - London: 1999) 
K. Bowie, “"A legal limited monarchy': Scottish constitutionalism in the Union of Crowns, 1603-1707”, Journal of Scottish Historical Studies 35 (2015), 131-154

J. Buchan, Theses Philosophica (Aberdeen: 1681, King's College)

T. Burnet, Theses Philosophica (??: 1686, ??)

A. Broadie, A History of Scottish Philosophy (Edinburgh: 2009)

A. Broadie, "James Dundas on the Hobbesian State of Nature", Journal of Scottish Philosophy 11 (2013), 1-13

Ronald G. Cant, "Origins of the Enlightenment in Scotland; the Universities", in R. H. Campbell and A. Skinner, The Origins and Nature of the Scottish Enlightenment (Edinburgh: 1982), 42-63

Alexander Cockburn, Theses philosophica (Edinburgh, 1675, St Leonard's College)

J. Dalrymple, Physiologia Nova Experimentalis (Leiden: 1686)

J. Dundas, Idea Philosophice Moralis (1679)

George Fraser, Positiones aliquot philosophicae (Aberdeen, 1691, King's College)

Alexander Fraser, Determinationes philosophicae (Aberdeen, 1693, Marischal College)

G. Gellera, "The Philosophy of Robert Forbes: a Scottish Scholastic Response to

Cartesianism” Journal of Scottish Philosophy 11.2 (2013): 191-211.

G. Gellera, "The reception of Descartes in the seventeenth-century Scottish universities: metaphysics and natural philosophy (1650-1680)”, Journal of Scottish Philosophy 13 (2015), 179-201

M. B. Gill, "From Cambridge Platonism to Scottish Sentimentalism”, Journal of Scottish Philosophy 8 (2010), 13-3

A. Guerrini, "The Tory Newtonians: Gregory, Pitcairne, and Their Circle”, Journal of British Studies 25 (1986), 288-311

R. Hamilton, Schediasmata Libero-Philosophica (Edinburgh: 1668, St Salvator's College)

P. Harrison, "Physico-Theology and the Mixed Sciences: The Role of Theology in Early Modern Natural Philosophy," in P. R. Anstey and J. A. Schuster (eds), The Science of Nature in the Seventeenth Century. Patterns of Change in Early Modern Natural Philosophy (Dordrecht: 2005), 165-184

J. Henry, The Reception of Cartesianism, in P. R. Anstey (ed.), The Oxford Handbook of British Philosophy in the Seventeenth Century (Oxford: 2013), 116-143

D. Hume, A Treatise of Human Nature, edited by L. A. Selby-Bigge (Oxford: 1960)

S. Hutton, "From Cudworth to Hume: Cambridge Platonism and the Scottish Enlightenment", Canadian Journal of Philosophy 42 (2012), 8-26 
S. Hutton, British Philosophy in the Seventeenth Century (Oxford: 2015)

R. Kennedy, Theses hasce Philosophicas (Edinburgh: 1694, University of Edinburgh)

J. Loudon, Theses Philosophica (Edinburgh: 1697, St Leonard's College)

G. Mackenzie, Religio Stoici (1663)

Gilbert MacMurdo, Theses hasce Philosophicas (Edinburgh, 1682, University of Edinburgh)

J. Martin, Positiones Philosophicae (Edinburgh: 1681, ??)

A. Massie, Theses Philosophicae (Edinburgh: 1687, University of Edinburgh)

G. Middleton, Theses philosophicae (Aberdeen: 1675, King's College)

A. More, Theses Philosophica (Aberdeen: 1691, Marischal College)

G. Peacock, Theses Philosophica (Aberdeen: 1689, Marischal College)

G. Peacock, Theses Philosophica (Aberdeen: 1693, Marischal College)

G. Peacock, Theses Philosophica (Aberdeen: 1697, Marischal College)

G. Peacock, Theses philosophicae (Aberdeen: 1711, Marischal College)

A. Raffe, "Intellectual change before the Enlightenment: Scotland, the Netherlands and the reception of Cartesian thought, 1650-1700”, Scottish Historical Review, 94 (2015), 24-47

William Sanders, Theses Philosophicae (Glasgow, 1674, St Leonard's College)

Gilbert MacMurdo, Theses hasce Philosophicas (Edinburgh, 1682, University of Edinburgh)

H. Scougal, Positiones hasce Philosophicas (Aberdeen: 1673, King's College)

C. M. Shepherd, Newtonianism in Scottish Universities in the Seventeenth Century, in R. H.

Campbell and A. Skinner, The Origins and Nature of the Scottish Enlightenment (Edinburgh: 1982), 65-85

G. Skene, Decermina haec Philosophica (Aberdeen: 1696, King's College)

P. Wood, The Aberdeen Enlightenment: the Arts curriculum in the Eighteenth Century (Aberdeen: 1993)

P. Wood, Candide in Caledonia: the Culture of Science in the Scottish Universities, 1690-1805, in M. Feingold (ed.), Universities and Science in the Early Modern Period (Dordrecht: 2006), 182-199 